\title{
Bernhard Häring CSsR - ojciec (po)soborowej teologii moralnej?
}

Wysunięcie dyskusyjnej tezy w tytule wystawia na ryzyko podrażnienia audytorium. Nie ułatwia sprawy opatrzenie zagadnienia znakiem zapytania. Jednakże warto zaryzykować. Mijające bowiem 20 lat od śmierci o. Bernharda Häringa (1912-1998) ${ }^{1}$ dają okazję do przyjrzenia się mu z pewnym obiektywizującym dystansem. Ułatwia to dostrzeżenie pewnych elementów jego dziedzictwa, które 20 lat wcześniej wydawały się co najwyżej ziarnem, dopiero co posianym, a obecnie ujawniają się jako coś o wiele bardziej rozwiniętego, o prawdziwie trwałym i profetycznym charakterze ${ }^{2}$.

Data niniejszej sesji naukowej, 10 listopada 2018, zbieżna jest z dniem urodzin naszego Autora. Przyszedł on na świat 10 listopada 1912 roku.

2 Niniejszy przyczynek odzyskuje częściowo dla polskiego czytelnika studium opublikowane przy okazji 10. rocznicy śmierci o. Bernharda: A.S. Wodka, La Parola di Dio nella teologia di Bernhard Häring, „Studia Moralia” 47 (2009), s. 39-60 (suppl. 4: Parola di Dio e morale. Atti della giornata di studio, Accademia Alfonsiana, Roma, 20.11.2008). 


\section{Wychowawca tysięcy moralistów}

Zastanawiano się już nad tym, czy ktoś inny przyczynił się do odnowy teologii moralnej w większym stopniu niż redemptorysta Bernhard Häring. Werdykt na jego rzecz wydał w tej kwestii np. Vincent MacNamara ${ }^{3}$. Terence G. Kennedy, współbrat i uczeń Häringa, a także jego kolega w nauczaniu w Akademii Alfonsjańskiej, nie zawahał się nazwać go wprost „ojcem współczesnej teologii moralnej"4. Stąd nasze dzisiejsze refleksje.

Chodzi o dyscyplinę, która $\mathrm{z}$ najwyższym trudem - przez ostatnie ponad 400 lat - walczyła o swój status naukowy, zdobywając go dopiero w czasach najnowszych, a decydujące było tu „wyzwolenie” moralności z oków prawa. Przewrót iście kopernikański nastąpił z chwilą, kiedy usytuowano teologię moralną w domenie duchowości, pojętej jako przestrzeń i czas, w których Bóg, własnymi sposobami, dosięga konkretnego człowieka w jego egzystencji, obdarowując go sobą oraz zdolnością do wzajemności w darze, a wszystko we wspólnocie ludzi odkupionych i zaproszonych do zbawczego dialogu.

Teologia moralna stała się naprawdę sobą z chwilą, kiedy sacri canones ustąpiły miejsca Objawieniu i jego szczególnej mocy „powołującej”. Widocznym znakiem tego życiodajnego przewrotu było określenie misji tej dyscypliny przez Sobór Watykański II, przy osobistym współudziale naszego Profesora. To właśnie dzięki niemu, we współpracy z innymi moralistami, jak Domenico

3 „(...) it is doubtful if anyone contributed more to the general spirit of renewal than Häring"; V. MacNamara, Faith and Ethics: Recent Roman Catholicism, Dublin 1985, s. 33.

4 T. Kennedy, Bernard Häring, CSsR, Father of Modern Moral Theology, „Liguorian” 87 (1999), nr 2, s. 18-21. 
Capone CSsR, możemy przeczytać w dekrecie o formacji kapłańskiej Optatam totius:

Szczególną troskę należy skierować ku udoskonaleniu teologii moralnej, której naukowy wykład karmiony w większej mierze nauką Pisma świętego niech ukazuje wzniosłość powołania wiernych w Chrystusie i ich obowiązek przynoszenia owocu w miłości za życie świata 5 .

Sądzimy, że o. Bernhard Häring może być uznany za ojca przed- i posoborowej teologii moralnej m.in. dlatego, że sam podjął niełatwe zadanie osadzenia dyskursu o ludzkim działaniu w czasoprzestrzeni powołania poprzez radykalny powrót do źródła, to jest do słowa Objawienia, jeszcze zanim zaczęto myśleć o Vaticanum II.

$\mathrm{Na}$ długiej i niełatwej drodze odnowy teologii moralnej $\mathrm{Na}$ uka Chrystusa (Das Gesetz Christi) najpierw oraz Free and Faithful in Christ później stały się podręcznikami, które uformowały setki moralistów. Według historyka Ottona Weissa, można się doliczyć ponad trzech tysięcy osób, które studiowały w bezpośrednim kontakcie $\mathrm{z}$ tym nauczycielem par excellence katolickiej teologii moralnej'.

Pamięć o szczególnym ojcostwie Häringa dla nowego ujęcia nauki o czynieniu dobra przez człowieka określonego historycznie i kulturowo zachował również papież Franciszek. Rozmawiając z jezuitami podczas ich kongregacji generalnej 24 października 2016 roku, stwierdził: „Myślę, że to Bernhard Häring jako

5 Optatam totius, nr 16. W tym samym numerze, nieco wcześniej, stwierdza się, że poniekąd „duszą teologii” ma być Pismo Święte („Scriptura sit veluti anima theologiae").

6 O. Weiss, Bernhard Häring, „Biographisch-Bibliographisches Kirchenlexikon” XVII (2000), kol. 563. 
pierwszy rozpoczął poszukiwanie nowej drogi, aby teologia moralna na nowo rozkwitła"

W niniejszym studium proponujmy zatem tezę, że Bernharda Häringa można uznać za ojca nowoczesnej teologii moralnej przede wszystkim z powodu odważnego odniesienia jej teologicznego statusu do Objawienia Bożego, zawartego w świadectwie Pisma Świętego obu Testamentów.

Obecność słowa Bożego w teologicznej twórczości Häringa jest uznawana za wystarczająco bogatą, by stanowić zasadniczy znak nowości, mimo że Autor nie był „profesjonalnym” biblistą. Jak ujawnia bibliografia, twórczość ta liczy ok. 1400 pozycji ${ }^{8}$ w postaci książek, artykułów i innych publikacji, o różnym kręgu odbiorców. Nie jest więc zaskakujące, że w przeszłości kuszono się na jej podstawie nawet o przewody doktorskie, skupiające się zwłaszcza na okresie bezpośrednio przedsoborowym i posoborowym, wokół punktu uznawanego za zwrotny, mianowicie wokół dzieła Nauka Chrystusa ${ }^{9}$.

7 Franciszek, „Avere coraggio e audacia profetica”. Dialogo di papa Francesco con i gesuiti riuniti nella $36^{a}$ Congregazione Generale, „La Civiltà Cattolica” nr 3995 (10.12.2016), s. 421. W rozmowie ze współbraćmi Ojciec święty zaproponował synom św. Ignacego refleksję moralną opartą na rozeznaniu. Zapytano go więc: „Jaką zatem mamy podjąć drogę na polu moralności w oparciu o dynamikę rozeznania (discernimento) sytuacji etycznych? Chyba nie chodzi o takie podejście do normy, jakoby wszystkie sytuacje szczególne były wyłącznie kazusami normy ogólnej”. Swoją odpowiedź papież Franciszek rozpoczął od wspomnienia Bernharda Häringa jako pierwszego „odnowiciela” teologii moralnej.

8 Dokładnie 1396 pozycji; zob. A. Owczarski, Bibliografia di P. Bernhard Häring, C.SS.R. (1912-1998), „Spicilegium Historicum CSsR” 56 (2008), s. 403-537.

9 Por. L. Abdamloora, Some Modern Attempts Towards Biblical Renewal in Moral Theology (praca doktorska, Pontificia Università Gregoriana, 1975); M. Clark, The Use of Sacred Scripture in the Moral Theology of Father 


\section{Nie zza zielonego stolika}

Postać tak imponująca w swojej teologicznej i duszpasterskiej płodności nie przychodzi znikąd, niczym deus ex machina. Również w przypadku tego słynnego teologa istnieje szczególne Sitz im Leben, które wyznaczyło jego rozwój, aż stał się osobowością kluczową w soborowej katolickiej teologii moralnej. We wstępie do Free and Faithful in Christ ${ }^{10}$ o. Bernhard tak pisze o sobie:

Urodziłem się w małym średniowiecznym miasteczku w południowo-zachodniej części Niemiec, przed pierwszą wojną światową. Moje dzieciństwo zostało ukształtowane przez klimat kochającej się rodziny, ale także zostało naznaczone bolesnym doświadczeniem cierpienia i straty, spowodowanym przez wojny. Jako student byłem w kontakcie z dorobkiem najważniejszych myślicieli, takich jak Max Weber i Max Scheler, a także wielkich przedstawicieli personalizmu, jak Martin Buber i Ferdinand Ebner. Byłem też entuzjastycznym zwolennikiem odnowy liturgicznej. Ale tym, co przyniosło przełom w moim myśleniu o teologii moralnej, była postawa niemądrego i wprost kryminalnego posłuszeństwa tak wielu chrześcijan wobec nazistowskiej tyranii zła. To doprowadziło mnie do przekonania, że charakter chrześcijanina nie powinien być kształtowany jednostronnie jedynie przez motyw przewodni „posłuszeństwa”, ale raczej Leitmotiv odpowiedzialności, która umie rozeznać, w połączeniu ze zdolnością dania śmiałej odpowiedzi na postrzegane

Bernhard Häring, C.Ss.R. (praca doktorska, Pontificia Università Gregoriana, 1979), zreasumowana przez autora w artykule The Major Scriptural Themes in the Moral Theology of Father Bernhard Häring, „Studia Moralia” 30 (1992), s. 3-16.

10 Free and Faithful in Christ. Moral Theology for Priests and Laity, t. 1-3, Slough 1978-1981 (późniejsze wydanie jako tłumaczenie na język niemiecki: Frei in Christus. Moraltheologie für die Praxis des christlichen Lebens, Freiburg-Basel-Wien, 1979-1981). 
przez ludzi nowe wartości i nowe potrzeby, w gotowości do podejmowania ryzyka ${ }^{11}$.

Ten zwięzły tekst ujawnia ewolucję wywołaną przez doświadczenia życiowe zakonnika o alfonsjańskiej duszy. Duch św. Alfonsa nie pozwala nam bowiem „pójść dalej”, gdy spotykamy człowieka w żałosnym stanie opuszczenia. Wprost przeciwnie, ta „redemptorystowska dusza” sprawia, że musimy przekroczyć wszelkie granice, aby wylać, swobodnie i hojnie, olej pocieszenia na każdą ranę, pomijając czysto ludzkie kryteria. Katastrofa wojenna w przypadku naszego Autora obnażyła fałszywe podstawy bezpieczeństwa zamkniętego w sterylnej samowystarczalności. Kontakt $\mathrm{z}$ ludźmi, niewinnymi ofiarami bezprecedensowego barbarzyństwa, popchnie Häringa w kierunku samego „szpiku” biblijnego Objawienia: będzie to odkrycie Shalom, tego pokoju, który leczy, ale który trzeba wciąż budować, aby nazywać się synami Boga (por. Mt 5, 9).

Jest to rodzaj egzegezy poniekąd „empirycznej”, spowodowanej przez biblijny peirasmós, to znaczy przez realną pokusę i zarazem próbę (test), która obala rusztowania „nauki” nastawionej na samą siebie, pozostawiając jedynie głęboką prawdę o Życiu. Jest to „egzegeza” inspirowana miłosierdziem, odkryta przez Häringa, paradoksalnie, właśnie w trudnych czasach nazistowskiej katastrofy. Sprawi ona, iż nasz Autor zrozumie swoją posługę w kategoriach nie tylko samej dobroci (benignitas), tak doktrynalnej, jak i duszpasterskiej, lecz także uwypukli dążenie do ekumenizmu i pragnienie rozwijania wszelkiego dialogu międzyludzkiego. Te wartości nigdy go już nie opuszczą.

11 Tłumaczenie własne na podstawie wydania włoskiego: B. Häring, Liberi e fedeli in Cristo. Teologia morale per preti e laici, Cinisello Balsamo 19821990, t. I, s. 12. 
Doświadczenia służby kapłana sanitariusza na polu walki, a następnie praca duszpasterska po zakończeniu konfliktu wojennego i narastający dialog z kulturą, coraz bardziej oddaloną od Boga, zrodziły teologię moralną Häringa w większym stopniu niż rygorystyczne prace badawcze za zielonym stolikiem. Towarzysząc zaś Niemcom przesiedlonym po konflikcie wojennym i pozbawionym domów (w ramach tzw. duszpasterstwa z plecakiem), o. Bernhard nauczył się jeszcze lepiej najpierw słuchać, a dopiero potem udzielać odpowiedzi. Zwierzał się:

Poświęcałem tej działalności średnio dziesięć tygodni w roku, dokładnie w okresie, w którym pracowałem nad moim dziełem Das Gesetz Christi. Te dwa pola pracy były ze sobą powiązane. Był to też duchowy exodus. (...) Nie użyłem żadnego z szesnastu kazań, które przygotowałem, ponieważ od razu zrozumiałem, że trzeba słuchać ludzkich potrzeb i odpowiadać na pytania. Często spałem $\mathrm{z}$ biedną rodziną uchodźców $\mathrm{w}$ tym samym pokoju. (...) $\mathrm{Z}$ duszpasterskiego punktu widzenia był to zysk. Jak to jest możliwe, aby głosić dobrą nowinę ludziom bez ojczyzny i w nędzy, jeśli nie stajemy się jednymi z nich, aż do granic możliwości? To właśnie wówczas, pracując z uchodźcami, poświęciłem się badaniu i nauczaniu teologii moralnej ${ }^{12}$.

Tak właśnie zrodził się Bernhard Häring - teolog moralista. Jego praca została potem uznana za „najbardziej twórcze i ważne osiągnięcie teologii moralnej"13 w stuleciu, które zamknęło drugie milenium ${ }^{14}$. W tle mieści się jednakże „przyspieszenie” nadchodzącego soboru...

B. Häring, Un'autobiografia a mo' di intervista, Milano 1997, s. 40-41.

C. Curran, Free and Faithful in Christ: A Critical Evaluation, „Studia Moralia" 20 (1982), s. 145.

14 Generalnie uznaje się Häringa, w całym jego dorobku, za jedną z najbardziej reprezentatywnych postaci katolickiej teologii moralnej. W dziele odnowy tej dyscypliny jego zasługi są porównywalne do dokonań Karla 


\section{Wielki znak czasów: Sobór Watykański II}

Bernhard Häring napisał swoje Das Gesetz Christi jeszcze w latach pięćdziesiątych, na długo przed zwołaniem Vaticanum II $(1954)^{15}$. Dzieło to świadomie i odważnie przetwarzało tradycję podręczników z poprzednich trzech stuleci. Przetłumaczone na 14 języków stało się najbardziej studiowaną księgą teologii moralnej w XX wieku ${ }^{16}$. Autor opracowuje w nim swoją wizję „moralności dynamicznej”, opartą na zasadzie wolności i odpowiedzialności, zrozumianą dogłębnie na tle osobistego niszczycielskiego doświadczenie nazizmu. Praca ta uświadomi wielu ludziom, w jaki sposób można wyłożyć i rozwijać teologię moralną jako naukę stale „powracającą do swoich źródeł, to znaczy do słowa Bożego i wielkich tajemnic wiary"17.

Nic dziwnego, że nasz Autor zostanie uznany za biegłego (peritus) soboru, ze względu na sprawdzoną solidność jego doktryny, a zarazem ze względu na jego odważne aggiornamento natury pastoralnej. Jako ekspert soboru będzie, jak już wspomnieliśmy,

Rahnera w zakresie odnowy teologii dogmatycznej; B. Mondin, Dizionario dei teologi, Bologna 1992, s. 299.

15 Pierwsze wydanie polskie: Nauka Chrystusa. Teologia moralna, tłum. J. Klenowski, t. I-III, Poznań 1962-1963 (pojawiło się też wydanie w czterech tomach, Poznań 1962-1966).

16 „(...) no book of moral theology has been translated into more languages and used by more people than Häring's Law of Christ"; C. Curran, Free and Faithful in Christ: A Critical Evaluation, dz. cyt., s. 145. Pisze na ten temat, 25 lat później, także R. Gallagher, Bernhard Häring's The Law of Christ. Reassessing its Contribution to the Renewal of Moral Theology in its Era, „Studia Moralia” 44 (2006), s. 317-351.

17 R.M. Gula, Reason Informed by Faith: Foundations of Catholic Morality, New York-Mahwah 1989, s. 29. Autor już w pierwszym dziele Häringa widzi prawdziwą magna charta teologii moralnej. 
bezpośrednio odpowiedzialny za słynną definicję nowej teologii moralnej w dekrecie Optatam totius. To ujęcie, w swojej genialnej prostocie językowej i w mocy przekazu biblijno-teologicznego, nada ton posoborowej nauce moralnej, rozumianej jako „teologia” (a nie tylko etyka), tj. dyscyplina, która jest w stanie przeanalizować i wyrazić ludzkie działanie także w sensie normatywnym, sub luce Evangelii.

$\mathrm{Na}$ fali tej samej soborowej przemiany, 25 lat później, Häring poczuje się zmuszony do dogłębnej rewizji swoich poprzednich sformułowań, praktycznie aż do napisania nowego podręcznika: Free and Faithful in Christ (1978-1981). Praca ta potwierdzi zasadę odpowiedzialności, teraz jednak wyrażoną jako „twórcza wierność” w ramach „międzyludzkiej solidarności”.

Z pewnym zaskoczeniem musimy tu zauważyć, że Häringowe użycie natchnionego Słowa w teologii moralnej nie przyciągnęło szczególnej uwagi samych biblistów. Być może dlatego, że niemiecki moralista sam nie był „prawdziwym egzegetą”. To, co czynił w swojej teologii, można było oceniać jako akrytyczne, a nawet przedkrytyczne traktowanie Pisma Świętego, a takie nie interesowało fachowych egzegetów. Teologia moralna prawdziwie biblijna, jako wynik profesjonalnej egzegezy, wciąż czekała na swoje narodziny.

Häring jednak w całej swojej naukowej karierze jest dosłownie nienasycony w wychwytywaniu nowości w tym kierunku. Przykładem wrażliwości na konieczność naukowego dobrania odpowiedniej hermeneutyki może być jego pierwszy artykuł, opublikowany w redemptorystowskim czasopiśmie „Studia Moralia”, założonym w 1963 roku $^{18}$.

18 B. Häring, Heutige Bestrebungen zur Vertiefung und Erneuerung der Moraltheologie, „Studia Moralia” 1 (1963), s. 11-48. 
Istotnie, Häring sam będzie nieustannie kwestionował swoje podejście do słowa Bożego, pragnąc doskonalenia własnej hermeneutyki biblijnej. W tym kontekście wyznaje, iż wiele się nauczył od Franza Tillmanna czy od niemal współczesnego mu Rudolfa Schnackenburga i innych ${ }^{19}$. Jego własny paradygmat, a nawet sam modus componendi materiam, ma tendencję do ciągłego aktualizowania, zgodnie z zasadniczymi liniami wskazanymi przez całą Tradycję, której sercem jest słowo Boże. Dlatego nie zaskakuje przyjmowanie coraz to nowych kategorii biblijnych, wyłaniających się w opozycji do poprzednich, nieco skostniałych, choć szanowanych w tamtych czasach ${ }^{20}$.

\section{4. „Kanon” słowa Bożego \\ w głównych dziełach Häringa}

Biblijne odniesienia w obydwu podręcznikach naszego Autora przekraczają liczbę 3400 zacytowań $^{21}$. Byłaby to już książka sama w sobie. Z ciekawości można sprawdzić typowo „Häringowy

19 Tamże, s. 15-16.

20 „Theologia moralis quae semper aliquo modo "kerigmatica " esse debet, speciali studio excolit doctrinam de conversione, ita ut tota vita cristiana subiecta sit legi crescendi, i.e. conversioni continuae. Personalismo moderno (...) opponimus personalismum biblicum, qui exprimitur per caritatem tamquam formam internam existentiae christianae. Existentialismum paganum oppugnamus et aliquo modo redimimus per existentialismum christianum, qui libertatem filiorum Dei non quaerit in anomismo titanico, sed in plena disponibilitate erga gratiam Spiritus Sancti cum animo semper parato erga necessitates proximi"; tamże, s. 11-12.

21 Opieramy się tutaj na dogłębnych badaniach, które przeprowadził J.S. Siker, Bernhard Häring. The Freedom of Responsive Love w swoim cennym dziele Scripture and Ethics. Twentieth-Century Portraits, New York 1997, s. $59-79$. 
kanon biblijny". Ponieważ oba dzieła wyraźnie i wiernie koncentrują się na chrystologii ${ }^{22}$, pierwszą rzeczą, którą się zauważa, jest poniekąd naturalny fakt, że tylko ok. 600 cytatów pochodzi ze Starego Testamentu.

W ramach objawienia starotestamentowego Häring chętnie powraca do czterech materiałów biblijnych: historii stworzenia z Księgi Rodzaju, teofanii i nadania Prawa z Księgi Wyjścia, postaci Sługi Jahwe z Deutero-Izajasza oraz tradycji mądrościowej, szczególnie zawartej w Księdze Przysłów. Uderza niemal całkowity brak odniesień do proroków (Ozeasz czy Amos, tak przecież ważni w studiach moralnych, są wspomniani tylko 11 razy).

Jak to wyjaśnić? Decydujący jest tu punkt wyjścia: na pierwszym miejscu nie ma już Dekalogu, lecz Pawłowe „życie w Chrystusie”. Do tego należy dodać widoczną niechęć Häringa do każdego fałszywego obrazu Boga, w imię którego dokonano tylu okrucieństw, z czym od młodości czuł się zobowiązany walczyć. Nasz Autor wyznaje w jednym z listów: „Egzegeza nowszego typu pomogła mi ogromnie w uchwyceniu wielkich linii Bożego objawienia i przeciwstawieniu się jedynie ludzkim podejściom i tradycjom"23.

W przypadku Nowego Testamentu, zgodnie $\mathrm{z}$ inspirującą energią tytułów obu dzieł redemptorysty, starannie dobranych i opierających się na konkretnych tekstach, najwybitniejszym autorem biblijnym pozostaje św. Paweł. Jednakże najczęściej przywoływanym jest ewangelista Jan. W szczególności są to rozdziały 13-17 jego Ewangelii, tzw. mowy pożegnalne Pana, w których pulsuje centrum Janowego przesłania: nowe przykazanie

22 Por. S. Majorano, Bernhard Häring. La teologia morale rinnovata dalla cristologia, „Rassegna di Teologia” 41 (2000), s. 485-515.

23 J.S. Siker, Bernhard Häring. The Freedom of Responsive Love, dz. cyt., s. 61. 
wzajemnej miłości. Ponad 10 procent (ok. 400) wszystkich odniesień biblijnych pochodzi właśnie z Jana.

Kolejnym bardziej znanym materiałem biblijnym używanym przez Häringa jest Mateuszowe Kazanie na górze (Mt 5-7). Nasz Autor widzi tu najwyraźniej wyrażone podstawy dla swojego rozumienia „nowego Prawa Ducha”. Jeśli zatem istnieje pewien rodzaj „praktycznego kanonu Häringa”, to w znacznym stopniu można go znaleźć u Jana 13-17 i u Mateusza 5-7.

Do nich dołącza oczywiście apostoł Paweł ${ }^{24}$. Często cytowane są bogate fragmenty z Listu do Rzymian 5-8. Także Pierwszy List do Koryntian cieszy się pewnym uprzywilejowaniem. Pisma deutero-Pawłowe są również obecne, zwłaszcza listy do Efezjan i do Kolosan (Häring nigdy jednak nie pyta o ich autorytatywność związaną z kwestią autentyczności). Do tego musimy dodać listy katolickie. Dość wyraźne są odniesienia do Listu do Hebrajczyków. Pierwszy List Jana zaś jest cytowany - proporcjonalnie - częściej niż jakakolwiek inna księga Nowego Testamentu (143 odniesienia).

Uczeni zauważają, że nie ma zasadniczej zmiany w tym „repertuarze" w ciągu 25 lat, które dzielą oba podręczniki. Pojawia się jednak pewna niespodzianka: Free and Faithful in Christ używa „tylko” ok. 50 procent odniesień obecnych w Nauce Chrystusa (ok. 1200 na 2400). Materiał z ksiąg mądrościowych również zostanie mocno zredukowany (z 71 cytatów z Księgi Przysłów pozostanie pięć, a z 33 z Mądrości Syracha jedynie trzy).

24 Już od pierwszego wydania Das Gesetz Christi (1954) Häring starał się stworzyć własną syntezę pomiędzy wizją synoptyków, św. Jana i św. Pawła. Ujął to w haśle „być i żyć w Chrystusie”; B. Häring, Teologia morale verso ilterzo millennio, Brescia 1990, s. 10. 
Pierwszą przyczyną tych zmian jest objętość nowego podręcznika, celowo zmniejszona o ok. 400 stron. Kolejny powód jest jeszcze bardziej znaczący: Häring stopniowo odchodzi od tradycyjnego odwoływania się do Pisma, jak to czynił w początkowej formacji teologicznej. Chodzi oczywiście o tzw. dicta probantia, to znaczy używanie Pisma Świętego jako źródła wtórnego - niemal ozdobnego - by potwierdzić teologiczno-moralną argumentację przeprowadzoną autonomicznie w oparciu o argumentację rozumową (i prawo naturalne), nie pozwalając jej na wyłonienie się ze świadectwa Pisma Świętego.

Radykalna redukcja materiału mądrościowego może być postrzegana jako rezultat kolejnej postępującej zmiany odnośnie do centralnego zagadnienia etycznego w teologii moralnej Häringa. Nie chodziło już o pytanie „co należy czynić”, ale raczej „kim powinno się być”, stając się osobą w harmonii z Bożym planem. Chodziło o przejście od rozważań wyłącznie parenetycznych do relacyjnej dynamiki wolności i twórczej wierności, co jest istotną cechą Häringowego podejścia do moralności, wyzwalającego się od chaosu mnogich „musisz” lub „nie możesz”25.

Idąc jeszcze dalej, możemy się pokusić o wskazanie tekstów najbardziej „ulubionych” przez Häringa. Ze Starego Przymierza wygrywa cytat $z$ Jeremiasza $31,31-34$. Jest to obietnica Boga o wyryciu nowego przymierza w ludzkich sercach (10 razy). Łatwiej to zrozumieć, biorąc pod uwagę akcent stawiany na dar nowej osobowości w Chrystusie. Z Nowego Testamentu dwa najczęściej cytowane teksty pochodzą z Ewangelii św. Jana 15, 12 („nowe przykazanie”, 16 razy) i z Listu do Rzymian 8, 2 („prawo

25 B. Häring, The Role of the Catholic Moral Theologian, w: Moral Theology: Challenges for the Future, red. C. Curran, New York-Mahwah 1990, s. 42. 
Ducha, który daje życie w Chrystusie", wyzwalając spod prawa grzechu i śmierci, 17 razy).

Nowe przykazanie wzajemnej miłości $(J 15,12)$ stanie się dla Häringa kluczem do fundamentalnego zrozumienia życia chrześcijańskiego i zarazem centralnym punktem jego teologii moralnej. Nowe przykazanie jest definiowane jako „najwyższe prawo” Chrystusa, jako synteza, która obejmuje wszystkie „przykazania docelowe”, uruchamiające dynamiczne zmierzanie do pełni moralności opartej na Przymierzu. Szczyt tego procesu wskazany jest w Ewangelii Mateusza 5, 48: „bądźcie doskonałymi, jak doskonały jest Ojciec wasz w niebie” (cytowane dziewięć razy). Tym właśnie tekstem biblijnym Häring ostatecznie wskaże, iż „prawem Chrystusa” jest przykazanie z Mt 6, 36: „bądźcie miłosierni”. Według naszego Autora, przykazanie to winno być traktowane jako obejmujące wszelkie Prawo, jako prawdziwie centralny paradygmat Biblii.

Häring aplikuje tę logikę także do swojej misji teologa: „Wypełnię moje trudne zadanie teologa moralisty, o ile w moim życiu osobistym, ale także w moim etosie i w działalności teologicznej będę się kierować dynamiką Jezusowego słowa: »Błogosławieni miłosierni, albowiem oni miłosierdzia dostąpią (Mt 5, 7)«”26.

Odnoszenie się do tych tekstów biblijnych ujawnia postępującą w Häringu przemianę. Jest to przejście od tradycyjnego zainteresowania o charakterze statycznym, typowym dla dawnej teologii moralnej, skupiającej się na kwestii grzechów i zakazów, do zaabsorbowania samym istnieniem, które odnawia się poprzez życie „w Duchu”, wsparte „przykazaniami docelowymi”, o dodatnim i dynamicznym ładunku.

26 Tamże, s. 37. 
Wielokrotne nawiązywanie do tekstu Rz 8, 2 („prawo Ducha, który daje życie w Chrystusie Jezusie, wyzwoliło cię spod prawa grzechu i śmierci”, 17 razy) jest natomiast typowe dla ciągłego stawiania akcentu na wolność osoby ludzkiej w Chrystusie. Nasz Autor często powołuje się także na Ga 6, 2 („dźwigajcie brzemiona jedni drugich, i w ten sposób wypełnicie prawo Chrystusowe”, dziewięć razy). Jest to sławny Leitmotiv, który da tytuł pierwszemu jego dziełu, Das Gesetz Christi (dosłownie „Prawo Chrystusa”). Inne teksty, przytaczane ze znaczną częstotliwością, poruszają tematy pokory (Mt 5, 3; 6, 16;11, 25; Łk 10, 21), po-

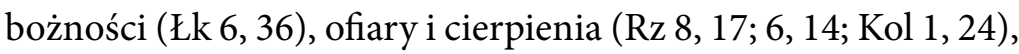
życia w prawdzie (J 8, 44; Ef 4, 15) i wzajemnej miłości (J 13, 34; Ga 5, 6; 1 J 4,8). Wszystkie te tematy są dla Bernharda Häringa „dominantami” moralności królestwa Bożego (motyw zaczerpnięty z Mk 1, 15 i Mt 4, 17).

Nie będąc prawdziwym Fachexeget, Häring dąży jednak coraz skuteczniej do tego, by nigdy nie lekceważyć krytyki tekstu, wiedząc, jak jej brak może wpłynąć na tłumaczenie (wcześniej nazbyt często „przybliżone”) i w konsekwencji dramatycznie przyczynić się do niewłaściwej interpretacji. Ostatecznie odważy się korygować pewne pojęcia cierpiące od wieków wskutek takiej właśnie niewłaściwej interpretacji, płynącej z poważnych nieścisłości egzegetycznych ${ }^{27}$.

Sam jednak tylko stopniowo uwalnia się od skłonności do korzystania z Pisma w jego dosłownym brzmieniu, pomijając pośrednictwo teologiczno-biblijne, by przechodzić od razu do

27 Widać to na przykładzie wykluczenia z królestwa Bożego osoby „seksu-

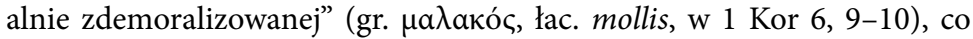
tradycja moralistyczna utożsamiała błędnie i bezkrytycznie z nawykiem masturbacji. 
wartości i norm moralnych ${ }^{28}$. Do końca będzie się starał aktualizować swoje poznanie, a nie po prostu kontynuować samodzielną twórczość bez oglądania się na społeczność naukową.

$\mathrm{Z}$ tego powodu znajdziemy częste ślady szczerej i widocznej progresywnej autokorekty w narastającym dialogu ze społecznością akademicką ${ }^{29}$. Bernhard Häring pozostanie więc teologiem moralistą, który - choć w coraz większym stopniu zaznajamia się $\mathrm{z}$ hermeneutyką - będzie jednak ciągle zależny od biblistów. Podobnie będzie w innych dziedzinach, np. w medycynie.

\section{Teologia moralna jako modlitewne echo Słowa}

W ożywianiu swojej teologii moralnej „duszą” Słowa Häring testuje też metodę „swobodnej inspiracji”, w której sugestywna refleksja natury aluzyjnej rodzi się spontanicznie i tworzy więź ze Źródłem, a zarazem „wzywa” do dania osobiście adekwatnej odpowiedzi w ludzkim czynie.

To podejście polega na przywoływaniu inspirujących tekstów, które nie wchodzą w argumentację, lecz pozostają obecne $\mathrm{w}$ tle. Są to dzisiejsze insights, impresje bez rozwinięcia, pozostawione czytelnikowi, być może $\mathrm{z}$ intencją wywołania swobodnej

28 Por. V. MacNamara, Faith and Ethics, dz. cyt., s. 33-35.

29 Francuskie (posoborowe) wydanie Das Gesetz Christi wydawca określa jako tekst „doskonały i w pełni potwierdzony przez Vaticanum II”. Ta ocena, dokonana bez konsultacji z Autorem, w jakimś sensie go przeraża: „Biada mi, jeśli w międzyczasie nie nauczyłem się wystarczająco wiele nowych rzeczy, by nie zrewidować odpowiednio moich poprzednich sformułowań!"; B. Häring, Teologia Morale verso ilterzo millennio, dz. cyt., s. 11 . 
kontemplacji, dla dalszego wybrzmienia różnych „sugestii”, lecz już na osobisty rachunek adresata tekstu.

Nie należy tu zapominać o stałej intencji wyraźnie obecnej w pracach Häringa. Jest on niemal „nękany” pragnieniem sprowadzenia teologii moralnej do jej duchowych korzeni, rozszerzając ją na oddech modlitwy, która jest przestrzenią kontaktu i spotkania ${ }^{30}$, a nie tylko troską o uzgodnienie doktryny moralnej z ludzkim życiem od strony ściśle i wyłącznie naukowej.

Nie są to dicta probantia w klasycznym znaczeniu, ponieważ Häring nie angażuje ich jako siły potwierdzającej jego argumentację racjonalną. Cytaty te są dodatkami w tekście, $\mathrm{z}$ wykorzystaniem efektu graficznego osobnych „okienek”. Rodzi się w ten sposób styl niemal homiletyczno-dialogiczny, który zmierza do tego, by słowo Boże rezonowało dodatkowo na swój sposób, także w przestrzeni ściśle argumentacyjnej, ale już przeniesionej w intymność ludzkiego podmiotu ${ }^{31}$.

Jest to przekształcenie „czystej” nauki w rodzaj liturgii, w której Słowo fascynuje czytelnika niemal sine glossa. Chodzi o to, by tekst brzmiał bardziej jako paraclesis (pocieszające dodanie odwagi i cierpliwego egzystencjalnego ukierunkowania) niż jako zwykła etyczna parenesis (instrukcja moralna dobrze umotywo-

30 Uderzająco brzmi tytuł jednego z dzieł duchowościowych Häringa: Prego perché vivo, vivo perché prego [Modlę się, bo żyję - żyję, bo się modlę], Assisi $1997^{2}$.

31 Warto przypomnieć wyjątkowo wybrzmiewające w tym kontekście cenne słowa Benedykta XVI, napisane siedem lat po śmierci o. Bernharda (2005): „Uwierzyliśmy miłości Boga - tak chrześcijanin może wyrazić podstawową opcję swego życia. U początku bycia chrześcijaninem nie ma decyzji etycznej czy jakiejś wielkiej idei, jest natomiast spotkanie z wydarzeniem, z Osobą, która nadaje życiu nową perspektywę, a tym samym decydujące ukierunkowanie"; Deus Caritas est, nr 1. 
wana, ale bez historycznego i personalnego kontekstu). Być może z tego powodu Häring będzie wielokrotnie głosił, że jego teologia moralna (jak i każda inna teologia moralna o katolickim charakterze) musi być zarówno naukowa, jak i kerygmatyczna: „Zamierzam wykazać, że powrót do wizji biblijnej może generować i uruchamiać energie wolności i twórczej wierności w dzisiejszym świecie" 32 .

Jeśli chodzi o autorytet Nowego Testamentu, Häring włącza się w interesującą dyskusję o wiążącej normatywnej wartości Mateuszowego Kazania na górze. Dokonuje tutaj nietypowego, ale z pewnością oryginalnego zbliżenia Mateusza do teologii Jana. Objawienie nowego Prawa na Górze Błogosławieństw (Mt 5-7) jest zupełnie inne od objawienia na górze Horeb (Wj 19, 9-25). Wszystko zasadza się na darze bliskości Boga w Jezusie, obiecanym Emmanuelu, w przeciwieństwie do przerażenia wywołanego objawieniem się całkowitej transcendencji Boga w Pierwszym Przymierzu. Nowe objawienie jest o tyle większe, o ile bardziej się uniża, aby zbliżyć maksymalnie Emanuela do ludzi. Umycie stóp (J 13, 1-15) pozostawia po sobie permanentny paradygmat (hypodeigma) prawdziwej szczęśliwości (beatitudo), która wyzwala moralność bliskości i miłosierdzia, wartości prawdziwie eschatologicznych i ostatecznych.

Dlatego właśnie w myśli Häringa te dwie osie (Mateuszowe Kazanie na górze i Janowe mowy pożegnalne Jezusa przed Paschą) pojawiają się jako fundament jego teologii moralnej nacechowanej wolnością i zarazem ufnością odzyskanego synostwa w jedynym Synu.

\footnotetext{
32 B. Häring, Liberi e fedeli in Cristo, t. I, dz. cyt., s. 245.
} 


\section{Chrystologiczny fundament teologii moralnej Häringa}

Ostatecznie Pismo Święte - słowo Boże, zachowa swój teologicznomoralny charakter normatywny w sensie „nowego Prawa Ducha”, uwalniając ludzką odpowiedź na dar i powołanie Boże w Chrystusie od zewnętrznej przymusowości, a dokonując jej progresywnego uwewnętrznienia $w$ ramach relacji synowskiej (wobec Boga) i braterskiej (wobec ludzi). Przykazania pozostaną, ale będą rozumiane w sposób analogiczny, jako „wskazania” lub „ukierunkowania” do etycznego maksimum, osiąganego w cierpliwym dialogu życia i kreatywnej wierności wołaniu Ewangelii, we wspólnocie Kościoła i świata. W ich negatywnym brzmieniu przykazania mogą zachować dotychczasową wartość potencjalnego minimalizmu, wskazując "jedynie” na to, co absolutnie nie powinno się wydarzyć, ze względu na niszczycielskie skutki złych wyborów, kontrastujących z najwyższą wartością daru odkupionego życia.

Charakter Häringowej teologii moralnej pozostaje zasadniczo niezmieniony, jeśli idzie o jej chrystologiczny fundament i moc działania. Chrześcijańska moralność, wypływająca radykalnie ze słowa Bożego wybrzmiewającego w przestrzeni „wzajemności sumień", pozostaje chrystologiczna ze względu na tajemnicę Wcielenia i Odkupienia. Chrystus-Słowo jest bowiem zarówno Światłem, jak i Rzeczywistością wyzwalającą, którymi można żyć w głębi ludzkiej podmiotowości, przekładając je w działaniu na „miłość responsorialną”, miłość odpowiadającą na Miłość.

W tym sensie prawdziwym „Ojcem” naszej moralności i jej intelektualnego uchwycenia w kategoriach wiary, która działa przez 
miłość $(\mathrm{Ga} 5,6)$, pozostanie Chrystus, żywy i działający w swoim Kościele $^{33}$. Duch Zmartwychwstałego prowokuje wszelki wzrost Ciała i ożywia wszystko, także to tajemnicze "promieniowanie ojcostwa” (K. Wojtyła, 1964), które odzwierciedla się w darach udzielonych dla budowania wspólnoty, a którego swoisty cień mogliśmy dostrzec w o. Bernhardzie.

\section{Towarzysz fascynującej podróży życia w więzi z Bogiem}

Dalsza historia oceni może nawet dogłębniej postać Bernharda Häringa i jego rolę w naukowym określeniu chrześcijańskiego życia w wolnej i odpowiadającej miłości (The Freedom of Responsive Love, J.S. Siker).

$\mathrm{Na}$ razie wybrzmiewają na ten temat opinie raczej ostrożne. Ostatecznie jednak cieszą nawet określenia mniej lub bardziej minimalistyczne, jak czyni to Wikipedia ${ }^{34} \mathrm{w}$ hasłach poświęconych

33 W tym sensie encyklika Lumen fidei papieża Franciszka (2013) przenosi poniekąd genezę „ojcostwa w wierze” z Abrahama (por. Rz 4, 16; Ga 3, 7) na Jezusa, „który zniósł ból i dlatego "nam w wierze przewodzi i ją wydoskonala " (Hbr 12, 2)" (nr 57). Papież odnosi się nawet do akt męczenników, które referują dialog rzymskiego prefekta Rusticusa z chrześcijaninem Hieraksem: „»Gdzie są twoi rodzice?« - pytał sędzia męczennika, a ten odpowiedział: »Naszym prawdziwym ojcem jest Chrystus, a naszą matką wiara w Niego« [Acta Sanctorum, I Junii, 21]. Dla tych chrześcijan - konkluduje Franciszek - wiara jako spotkanie z Bogiem żywym objawionym w Chrystusie była "matką", ponieważ wydawała ich na światło dzienne, rodziła w nich Boże życie, nowe doświadczenie, pełną blasku wizję życia, dlatego byli gotowi złożyć do końca publiczne świadectwo"(nr 6).

34 https://it.wikipedia.org/wiki/Bernhard_Häring (dostęp: 30 października 2018). 
naszemu Autorowi. Internetowy portal natychmiastowej, choć pigułkowej wiedzy mówi o nim w dziewięciu językach (2018).

Włoska wersja określa Bernharda Häringa jako ,jednego z ojców” odnowy teologii moralnej, uznając go przy tym za „największego teologa moralistę XX wieku”35. Polska strona przedstawia go jako ,jednego z odnowicieli” tej dyscypliny ${ }^{36}$. Francuski autor hasła stwierdza lakonicznie, iż Häring - co jest powszechnie znane - przyczynił się do „ukierunkowania teologii moralnej w stronę podejścia bardziej personalistycznego, opierającego się przede wszystkim na Piśmie Świętym"37. Niemiecki opis mówi odważniej o jego „założycielskiej roli” w kształtowaniu personalistycznej, biblijnie ukierunkowanej teologii moralnej, a także o jego dalszym wpływie na rozwój tej nauki, zwłaszcza przez ekumeniczną otwartość i dialog z nowoczesną, pluralistyczną kulturą ${ }^{38}$. Angielskie hasło przedstawia go zaś jako lidera katolickiej teologii moralnej, właśnie o bardziej personalistycznym charakterze i opartej na Objawieniu ${ }^{39}$.

Może najlepiej wyrobić sobie własną opinię - w szczerym dia$\operatorname{logu}$ z Autorem? Może dostrzeżemy w nim „towarzysza podróży”

35 Tamże: „considerato dai suoi successori (...) il più grande teologo morale cattolico del XX secolo. (...) Fu uno dei padri della Teologia morale contribuendo con molti scritti”.

36 Tamże: „Jest uważany za jednego z odnowicieli katolickiej teologii moralnej w XX wieku”.

37 Tamże: „Il a notamment contribué à orienter la théologie morale catholique vers une approche plus personnaliste, et reposant davantage sur l'Écriture".

38 Tamże: „Häring hat eine biblisch orientierte, personale Moraltheologiebegründet und die weitere Entwicklung dieser Disziplin maßgeblich beeinflusst. Ökumenisches Gespräch und Dialog mit der modernen, pluralistischen Kultur prägten zunehmend seine Arbeit” .

39 Tamże: „Häring established himself as a leader in moving Catholic moral theology to a more personalist and scripture-based approach". 
w przygodzie życia dającego odpowiedź odwiecznemu wołaniu Trójcy, poprzez moralność wolną „od” i „dla”, a zarazem wierną w ufnej twórczości nowych struktur życia, godnego Ewangelii? Oddajemy w tej materii ostatnie słowo właśnie o. Bernhardowi:

Całkowicie uwolnieni dla Chrystusa, jesteśmy także uwolnieni dla bliźnich. Jesteśmy wolni jako współdziałający i współtworzący z Bogiem Stworzycielem, Bogiem Artystą i Bogiem Odkupicielem. Przejście od przykazań ukazujących limit ku przykazaniom docelowym wytycza nam przestrzeń wolności twórczej. Musimy jednak rozumieć to „przejście” jako wyraz tej wolności, która stwarza czyste serce i nowe struktury życia. (...) Tylko ci, co znają prawdziwą naturę miłości, do której Chrystus nas powołuje, poznają także wymiary prawdziwej wolności i wierności w Chrystusie ${ }^{40}$.

40 B. Häring, Il carattere specifico della morale cristiana. In ascolto delle precise esigenze bibliche, w: Parola e Spirito. Studi in onore di Settimio Cipriani, red. C. Casale Marcheselli, Brescia 1982, t. II, s. 1218-1219. 